\title{
Terapi Vincristine dan Triamcinolone dalam pengobatan Hemangioma Infantil
}

\author{
Heru Noviat Herdata*, Djajadiman Gatot**, Endang Windiastuti** \\ * Bagian Ilmu Kesehatan Anak Fakultas Kedokteran Unsyiah / RSU Zainal Abidin Banda Aceh \\ ** Divisi Hematologi Onkologi Departemen Ilmu Kesehatan Anak, Fakultas Kedokteran \\ Universitas Indonesia, RS Dr. Ciptomangunkusumo Jakarta
}

\begin{abstract}
Latar belakang. Hemangioma infantil merupakan salah satu tumor jinak pada bayi dan anak yang diawali dengan bentuk noda kemerahan. Pada masa proliferasi, noda kemerahan ini dapat berubah menjadi bentuk nodul atau melebar serta membesar. Hingga saat ini belum ada terapi yang memuaskan, dan terapi dengan kortikosteroid sistemik merupakan pilihan yang mudah dan efektif meskipun hasilnya tidak seragam. Terapi alternatif lain telah dicoba yaitu vincristin atau interfensi alfa.

Tujuan Penelitian. Mengetahui sebaran, gambaran, komplikasi hemangioma serta mengevaluasi terapi kortikosteroid dan vincristine pada HI serta efek sampingnya.

Metode. Analisis retrospektif terhadap 26 pasien yang berobat jalan di Poliklinik Khusus Hematologi Onkologi Anak Fakultas Kedokteran Universitas Indonesia, rumah sakit Dr. Ciptomangunkusumo Jakarta mulai tahun 2005 - 2006, hasil terapi dinilai berdasarkan mengecilnya hemangioma.

Hasil. Hemangioma lebih banyak pada anak perempuan dengan bentuk morfologi segmental. Enam puluh sembilan persen hemangioma timbul setelah lahir dan terapi kortikosteroid diberikan terhadap $92 \%$ pasien, baik secara oral, maupun kombinasi suntikan intralesi atau dengan vincristine. Sebanyak $50 \%$ pasien mengalami perbaikan termasuk semua pasien yang diterapi kortikosteroid kombinasi dengan vincristine. Tidak ditemukan efek samping lokal, maupun sistemik akibat pemakaian kortikosteroid dan vincristin.

Kesimpulan. Kortikosteroid sistemik dan intralesi cukup efektif sebagai pengobatan HI, yaitu dengan pengecilan hemangioma serta tidak ditemukannya efek samping sistemik lokal, maupun sistemik. Vincristin dapat dipakai sebagai alternatif pengobatan HI yang resisten terhadap kortikosteroid (Sari Pediatri 2007; 9(10):59-66).
\end{abstract}

Kata kunci: hemangioma infantil, kortikosteroid, vincristin

\footnotetext{
Alamat korespondensi

Dr. Endang Windiastuti, SpA(K), Divisi Hematologi Onkologi Departemen Ilmu Kesehatan Anak FKUI- RSCM Jl. Salemba no. 6, Jakarta 10430. Telepon: 021-3907744, 31901170 Fax.021-3913982.
}

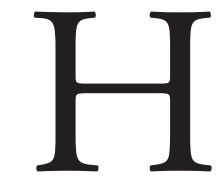
emangioma infantil (HI) merupakan tumor jinak yang berasal dari sel endotel pembuluh darah kecil berupa kapiler dan venula, yang muncul dan berkembang cepat sebelum ulang tahun yang pertama. 
Umumnya mudah dikenali dengan pengamatan saja. Sekitar 30 persen HI sudah tampak sejak saat bayi lahir, dan sisanya muncul setelah satu atau empat minggu setelah kelahiran. HI tiga kali lebih banyak pada anak perempuan dibanding lelaki, 22 persen bayi prematur dengan berat badan kurang 1000 gram. Tanda lahir ini juga lebih banyak muncul pada ras kaukasia. Sampai saat ini, belum diketahui pasti penyebab terjadinya hemangioma. Beberapa faktor yang mempengaruhi antara lain demografis, faktor prenatal dan perinatal serta riwayat pemeriksaan chrionic villous. ${ }^{1,3,4}$

Hemangioma infantil lebih sering ditemukan di daerah kepala dan leher (kira-kira 80\% kasus), jarang di anggota gerak dan alat genital. HI dapat menimbulkan gangguan, apalagi bila berada di sekitar bagian tubuh vital bahkan menjadi cukup berbahaya, bila sampai muncul di berbagai organ dalam tubuh., ${ }^{3,4}$ Dalam beberapa bulan pertama, sangat sulit untuk meramalkan proses dan prognosis pertumbuhan $\mathrm{HI}$ dan salah satu cara dengan pengukuran dan fotografi secara berkala.,

Telah banyak cara untuk mengobati HI, namun hingga saat ini belum diketahui cara pengobatan yang aman dan tuntas. Pilihan terapi pertama adalah dengan pemberian kortikosteroid secara sistemik, intralesi atau topikal. ${ }^{6-11}$ Sebagai pilihan terapi kedua dapat diberikan interferon alpha-2a dan $2 b,{ }^{12-13}$ sitostatik vincristine, ${ }^{14}$ bleomycin ${ }^{15}$ atau cyclophosphamide, ${ }^{19}$ pulse dye laser, ${ }^{4,17}$ embolisasi ${ }^{18}$ terapi krio, ${ }^{4}$ vasoligasi atau bedah plastik. ${ }^{17,19}$

Tujuan penelitian untuk mengetahui sebaran, gambaran, komplikasi hemangioma serta mengevaluasi terapi kortikosteroid dan vincristine pada HI serta efek sampingnya

\section{Metode}

Penelitian retrospektif deskriptif terhadap anak yang berobat jalan di Poliklinik Khusus Hematologi Departemen Ilmu Kesehatan Anak FK UI RSUPN Cipto Mangunkusumo Jakarta yang berkunjung pada tahun 2005 sampai 2006. Semua anak yang menderita HI berdasarkan pemeriksaan fisik diikutkan dalam penelitian ini. Diagnosis berdasarkan gambaran klinis HI. Data yang diambil meliputi anamnesis mengenai riwayat kehamilan, prematuritas, berat badan, riwayat keluarga dengan kelainan yang sama atau kelainan vaskuler lain, terapi yang telah diberikan, gejala lokal dan gejala sistemik.

Pemeriksaan fisik meliputi jumlah, letak anatomi, besar, keterlibatan mukosa, superfisial, dalam atau jenis campuran, dan kelainan morphologi. Hemangioma Infantil dikelompokkan berdasarkan lokasi, segmentasi (linear, unilateral atau menurut segmen dan dermatom tertentu, multipel (sendirian, bergerombol). Secara morfologi, HI dikelompokkan dalam berbentuk nodul, melebar datar, menonjol, datar telangiektasis, datar berpapul. Komplikasi karena HI dikelompokkan antara lain ulserasi, berdarah, nyeri, infeksi, jaringan parut, gangguan fungsi seperti gangguan makan, melihat atau pedengaran. Selain itu juga dicatat kelainan sistem misalnya hemangioma viseral, gangguan perkembangan dan komplikasi sistemik seperti gagal jantung, dan purpura.

Terapi diberikan berdasarkan kelainan yang didapat, yaitu triamsinolon oral $20 \mathrm{mg} / \mathrm{m} 2 /$ hari dibagi dalam 3 dosis, triamcinolon intralesi $0,5 \mathrm{ml} / \mathrm{minggu}$ (bila diameter $<2,5 \mathrm{~cm}$ ) atau triamsinolon topikal. Vincristine diberikan apabila tidak ada respon setelah pemberian kortiosteroid atau hemangioma yang luas (>10 cm) dengan dosis $0,05 \mathrm{mg} / \mathrm{kgBB} /$ minggu untuk yang berat badan kurang $10 \mathrm{~kg}$, atau $1,5 \mathrm{mg} / \mathrm{m} 2$ untuk berat badan yang lebih $10 \mathrm{~kg}$. Dicatat efek samping obat yang terjadi yaitu gejala sindrom Cushingoid, tekanan darah, dan gangguan gastrointestial. Hasil terapi dievaluasi dan dinilai berdasarkan pengecilan ukuran hemangioma (derajat dibagi menjadi derajat 1 bila $>50 \%$, derajat 2 bila $<50 \%$ dan dan derajat 3 bila tidak ada perubahan dan tidak bertambah besar).

\section{Hasil}

Terdapat 26 pasien hemagioma, terdiri dari 16 perempuan dan 10 laki-laki dengan rasio 1,6: 1 . Median umur pasien 6,5 bulan dengan rentang 1 bulan sampai 24 bulan. Tidak ditemukan riwayat kelahiran prematur dan terdapat 22 pasien baru yang belum diterapi, sisanya datang setelah tidak berhasil diterapi dengan kortikosteroid saja. Kasus HI yang ditemukan sejak lahir 18 pasien dan sisanya muncul beberapa minggu atau bulan setelah lahir. (Tabel 1)

Secara anatomi, letak kelainan yang banyak dijumpai di daerah muka 13, 8 di ektremitas, di badan 4 dan 1 pasien di genital.

Tipe kelainan yang terbanyak segmental 15 , nonsegmenal 10 dan 1 pasien multipel. Komplikasi lokal yang terjadi ialah perdarahan pada 8 , ulserasi 1 , infeksi 1 dan 14 pasien tanpa komplikasi. Tidak ditemukan 
Tabel 1. Karakteristik Klinis hemangioma infantil di Departemen Ilmu Kesehatan Anak Rumah Sakit Dr. Ciptomangunkusumo 2005-2006

\begin{tabular}{|c|c|c|c|c|c|}
\hline $\begin{array}{l}\text { Umur } \\
\text { bulan }\end{array}$ & $\begin{array}{c}\text { Lokasi } \\
\text { Hemangioma }\end{array}$ & Tipe & Bentuk & $\begin{array}{c}\text { Ditemukan } \\
\text { saat lahir }\end{array}$ & Komplikasi \\
\hline 4 & Lengan & Non segmental & Nodul & $\mathrm{Ya}$ & Berdarah \\
\hline 5 & Muka & Non segmental & Nodul & Tidak & Berdarah \\
\hline 1 & Muka & Segmental & Melebar & $\mathrm{Ya}$ & Berdarah \\
\hline 5 & Muka & Segmental & Melebar & Tidak & Berdarah \\
\hline 2 & Muka & Non segmental & Nodul & $\mathrm{Ya}$ & $(-)$ \\
\hline 5 & Kaki & Non segmental & Nodul & Tidak & $(-)$ \\
\hline 5 & Muka & Non segmental & Nodul & Tidak & $(-)$ \\
\hline 6 & Perut & Non segmental & Nodul & Tidak & Berdarah \\
\hline 7 & Genital & Segmental & Melebar & Ya & $(-)$ \\
\hline 24 & Kaki & Segmental & Melebar & $\mathrm{Ya}$ & $(-)$ \\
\hline 15 & Punggung & Segmental & Melebar & Tidak & Infeksi \\
\hline 8 & Muka & Non segmental & Nodul & $\mathrm{Ya}$ & $(-)$ \\
\hline 2 & Punggung & Segmental & Melebar & Tidak & $(-)$ \\
\hline 4 & Muka & Segmental & Melebar & $\mathrm{Ya}$ & Berdarah \\
\hline 2 & Muka & Segmental & Melebar & $\mathrm{Ya}$ & $(-)$ \\
\hline 8 & Lengan & Non segmental & Nodul & Ya & Berdarah \\
\hline 2 & Lengan & Segmental & Melebar & $\mathrm{Ya}$ & $(-)$ \\
\hline 10 & Muka & Segmental & Melebar & Ya & $(-)$ \\
\hline 18 & Muka & Segmental & Melebar & $\mathrm{Ya}$ & $(-)$ \\
\hline 12 & Kaki & Segmental & Melebar & Ya & $(-)$ \\
\hline 3 & Muka & Non segmental & Nodul & Ya & Berdarah \\
\hline 5 & Kaki & Multipel & Melebar & Ya & $(-)$ \\
\hline 1 & Muka & Segmental & Melebar & $\mathrm{Ya}$ & $(-)$ \\
\hline 9 & Punggung & Segmental & Melebar & Tidak & Ulserasi \\
\hline 3 & Kaki & Non segmental & Nodul & Ya & $(-)$ \\
\hline 3 & Muka & Segmental & Melebar & $\mathrm{Ya}$ & Berdarah \\
\hline
\end{tabular}

gejala berat lainnya seperti gangguan makan, komplikasi sistemik dan gangguan penglihatan sehingga seluruh pasien tidak dilakukan pemeriksaan lain untuk mencari keterlibatan hemangioma terhadap organ dalam tubuh.

Jenis pengobatan tertera pada Gambar 1, 24 pasien diberikan terapi kortikosteroid dan 2 pasien dilakukan observasi. Dari 24 pasien yang mendapat kortikosteroid, 4 pasien diberikan kombinasi terapi dengan vincristine. Pasien yang mendapat kortikosteroid (24 pasien), 12 diberi secara oral, 6 diberi kombinasi oral dan suntikan intralesi, sedangkan 2 orang lainnya mendapat kortikosteroid topikal.
Hasil pengobatan pada pasien dengan kortikosteroid oral (12 pasien) menunjukkan respon pada 5 pasien sedangkan 7 pasien lainnya tidak mengalami perbaikan. Respon terapi pada pasien yang mendapatkan kombinasi kortikosteroid oral dan intralesi (6 pasien), perbaikan pada 4 pasien dan 2 pasien tidak ada perbaikan. Seluruh pasien yang menggunakan terapi kombinasi kortikosteroid dan vincristin (4 pasien) semuanya mengalami perbaikan derajat 1 (Gambar 2). Secara keseluruhan respon terapi derajat 1 (pengurangan besarnya hemangioma lebih 50\%) $30 \%$, derajat 2 (kurang 50\%) 20\% dan derajat 3 (tidak berubah) $50 \%$. 


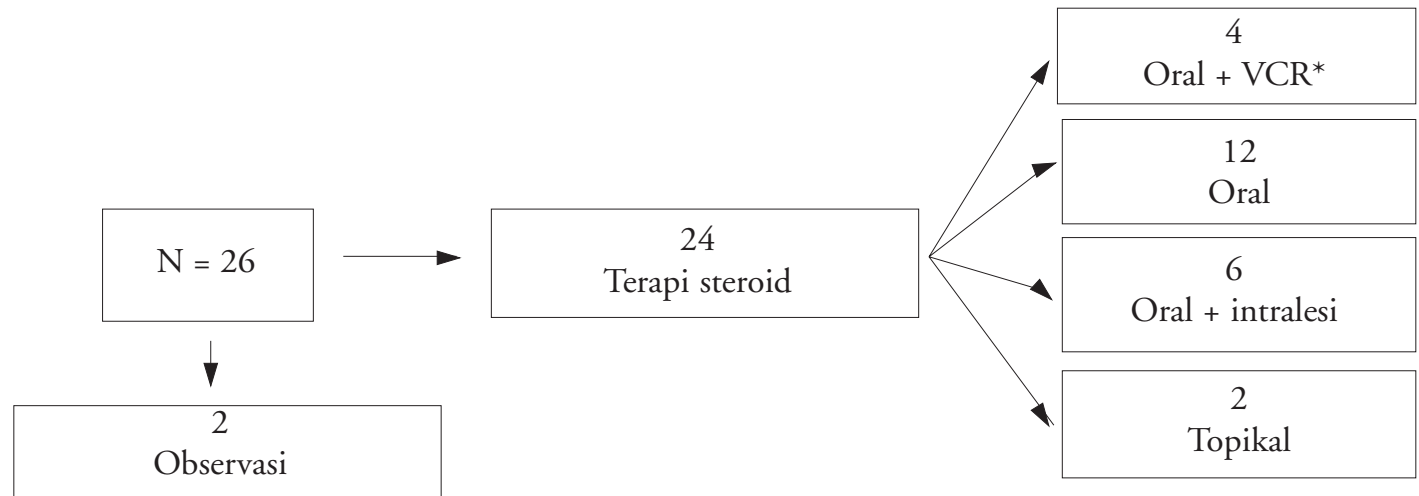

Keterangan: *VCR: Vincristine

Gambar 1. Jenis pengobatan pada 26 pasien hemangioma infantil.
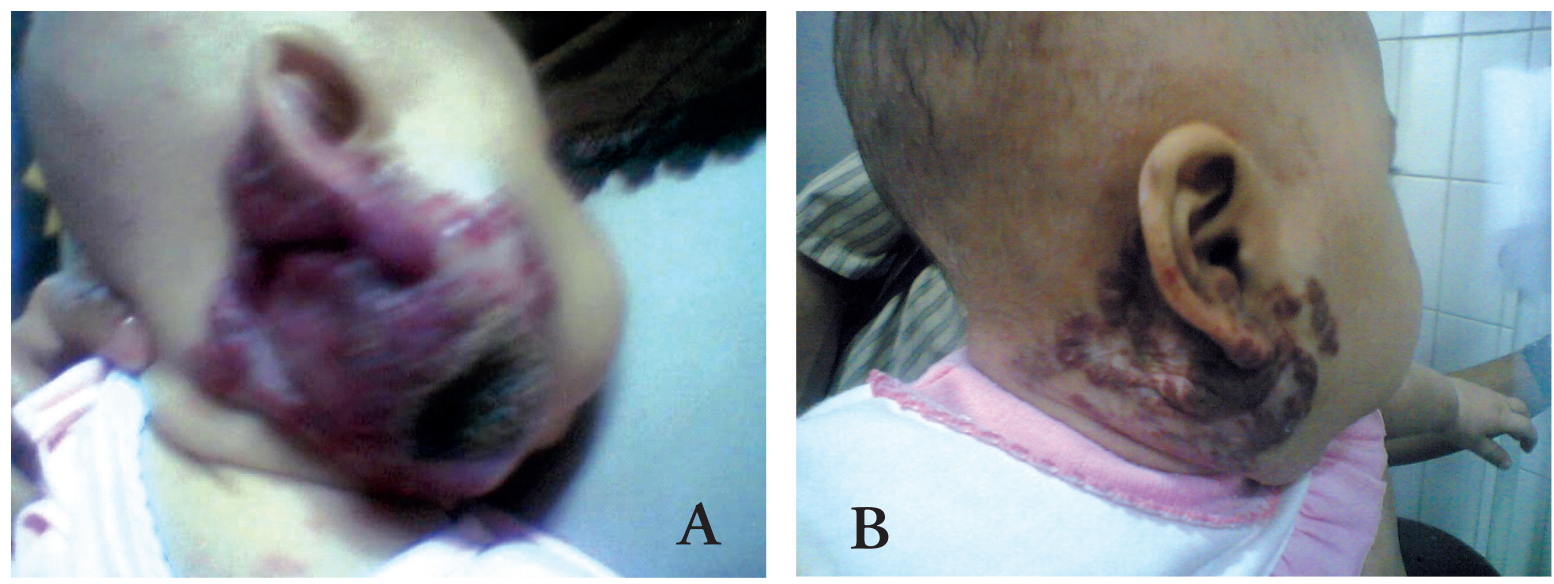

Gambar 2 A dan B. Pasien no 18 sebelum terapi (A) dan setelah terapi kortikosteroid + vincristine 4 minggu (B)

Tidak ditemukan gejala efek samping obat pada semua pasien, baik efek samping lokal dan sistemik. Dua pasien yang mendapat kortikosteroid lokal dan dua pasien tanpa pengobatan tidak mengalami perbaikan.

\section{Diskusi}

Patogenesis HI sampai saat ini belum sepenuhnya dipahami. Sari $\mathrm{dkk}^{20}$ mendapatkan adanya defek primer sel endotel bukan defek pada sel vaskuler. Mesenchim sel induk akan berkembang untuk membentuk stroma dari HI dan akan berperan sebagai cadangan fibro-fatty sebagai dukungan terjadinya involusi. Peneliti lain mendapatkan adanya mutasi pada chromosom 5q31-33. ${ }^{21,22}$
Hemangioma dibedakan menjadi hemangioma infantil dan hemangioma kongenital, hal ini berdasarkan saat timbulnya hemangioma dan proses perkembangannya. Hemangioma kongenital selalu telah ada dan telah berkembang maksimal saat bayi lahir dan tidak akan bertambah besar setelah lahir. Hemangioma kongenital dibagi atas jenis Rapid Involuting Congenital Hemangima (RICH) dan Non Involuting Congenital Hemangima (NICH) (Gambar 3).23

Hemangioma infantil (HI), merupakan salah satu tumor jinak pada anak yang sering terjadi, sekitar $2 \%$ bayi muda dapat menderita HI, prevalensi ini akan bertambah menjadi $10 \%$ pada bayi yang telah beumur lebih satu bulan. 1,3,17,21,24 Dikelompokkan berdasarkan besar kelainan, lokasi kelainan, dan subtipe bertujuan untuk membedakan pilihan pengobatan serta sebagai faktor prediksi terjadinya komplikasi. ${ }^{25,26}$ Hemangioma 


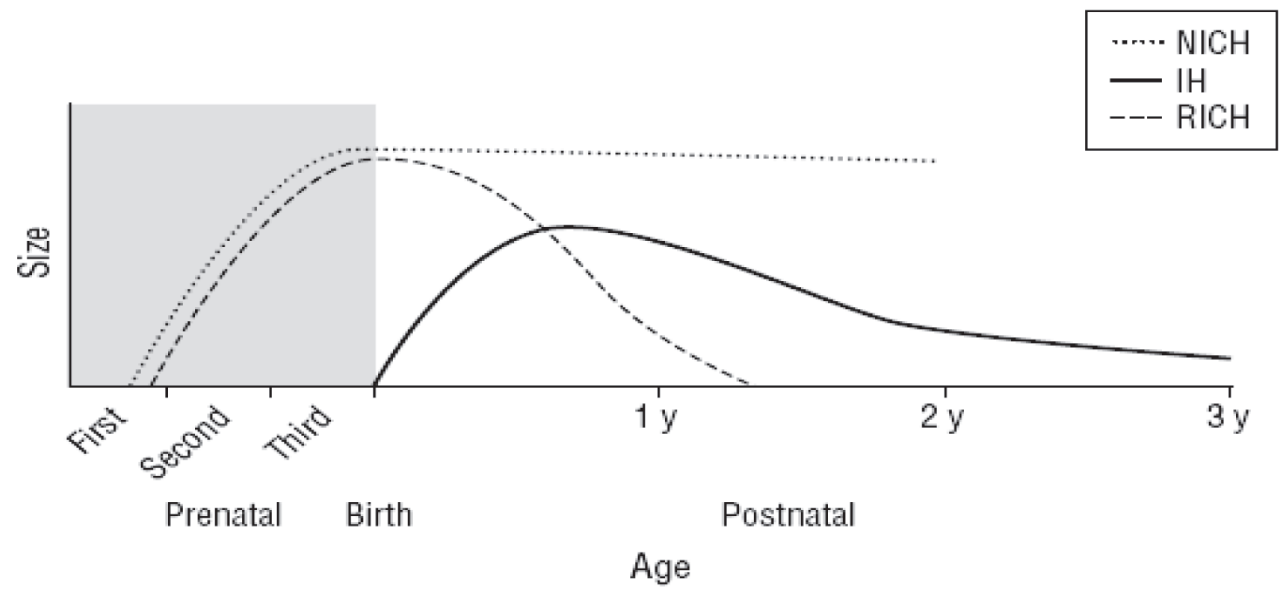

Gambar 3. Kurva pertumbuhan RICH, NICH dan Hemangioma Infantil (IH)

infantil pada awalnya dapat dimulai sebagai bentuk noda kemerahan, bercak seperti memar atau kadang dapat berupa kelainan bercak yang memucat. Selama masa proliferasi, kelainan ini dapat merubah menjadi bentuk nodul atau melebar dan membesar yang membedakan secara morfologi. ${ }^{27}$

Seperti hasil penelitian sebelumnya, penelitian ini mendapatkan hasil yang sama meliputi saat timbulnya HI, didominasi oleh perempuan serta distribusi secara anatomi. ${ }^{25,28}$ Tetapi ada perbedaan nyata yang didapatkan bahwa pada penelitian ini, yaitu tidak didapatkan riwayat kelahiran premature. Hal ini mungkin karena observasi yang kurang akurat dalam menentukan umur kehamilan yaitu dengan mengasumsikan bayi dengan berat badan lahir lebih besar 2500 gram dianggap sebagai kehamilan cukup bulan atau mungkin karena jumlah pasien yang sedikit dalam penelitian ini. Delapan orang pasien timbulnya hemangioma pada saat lahir, namun hemangioma tersebut bukanlah hemangioma kongenital.

Pengelompokkan letak kelainan HI yaitu segmental, non-segmental dan multifokal digunakan pada penelitian ini sesuai dengan yang dibuat oleh Chiller dkk. ${ }^{24}$ Mereka mengamati bahwa HI yang segmental atau mutifokal (dikatakan bila lebih dari 5 buah) secara nyata merupakan risiko tinggi untuk terjadinya komplikasi dan tingginya insiden keterlibatan organ dalam lainnya sehingga pada pasien ini perlu mendapat terapi invasif, pegawasan yang ketat, serta memerlukan terapi pembedahan dan terapi sistemik. Keterlibatan organ dalam sebagai ekstrakutaneus hemangioma yang paling sering adalah hati, saluran cerna, otak, mediastinum, dan paru. Selain itu HI segmental sering ditemukan pada bayi baru lahir dengan masa gestasi lebih tua dan berat badan yang lebih besar. ${ }^{29} \mathrm{Hal}$ ini tidak sesuai dengan yang didapat pada penelitian ini tidak mendapatkan hubungan antara HI yang segmental dengan masa gestasi, berat badan lahir atau keterlibatan organ dalam lainnya. Bentuk HI non-segmental berbentuk nodul dan melebar, merupakan bentuk kelainan yang sering didapat. ${ }^{24}$ Namun pada penelitian ini bentuk segmental lebih banyak ditemukan (15 pasien) dibandingkan bentuk non segmental 10 pasien.

Beberapa keadaan yang memerlukan evaluasi lebih jauh bila dijumpai HI periorbital yang menyebabkan gangguan visus yang permanen, $\mathrm{HI}$ cervicofacial dagu dan leher karena dapat mengganggu aliran saluran pernafasan HI lumbosacral sering dihubungkan dengan kelainan kongenital lain termasuk spinal dysraphism. ${ }^{26}$ Kasus HI yang lebar pada daerah muka, sebaiknya dilakukan evaluasi kemungkinan adanya sindrom PHACES (posterior fossa malformation, hemangiomas, arterial anomalies, cardiac anomalies and coartatio aorta, eye abnormalities, sternal cleft andlor supraumblical raphe)..$^{30,31}$ Bayi usia di bawah 3 bulan dengan hemangioma kulit yang kecil dan multipel mempunyai risiko adanya kelainan organ dalam tubuh yang dikenal sebagai diffuse neonatal hemangiomatosis. Sindrom lain yang dapat mengancam hidup anak adalah sindrom Kasabach Merrit, yaitu hemangioma luas yang berkembang secara cepat, disertai trombositopenia gangguan pembekuan darah. ${ }^{28,32}$ Pada keadaan ini perlu dilakukan pemeriksaan penunjang lain seperti periksaan darah perifer lengkap, uji fungsi hati, ultrasonografi, MRI/CT scan. ${ }^{12}$ Pemeriksaan biopsi jaringan hanya dilakukan bila dicurigai adanya 
keganasan atau suatu jenis kaposiform hemangio endotheliomas. ${ }^{33}$ Komplikasi sistemik dan gangguan organ dalam tubuh tidak ditemukan pada penelitian ini seperti sindrom Kasabach-Merrit, dan sindrom PHACES

Komplikasi lokal pada penelitian ini hampir sama dengan penelitian sebelumnya berupa perdarahan, ulserasi dan infeksi. Trauma fisik luar mungkin merupakan penyebab terjadinya ulserasi, perdarahan dan infeksi, sehingga penting untuk menerangkan kepada orang tua pasien agar menghindari terjadinya trauma pada hemangioma dan hal ini merupakan bagian yang penting dalam merawat kelainan tersebut. Gangguan fungsi karena sumbatan fisik terhadap telinga, mata, rongga mulut dan lain-lain memerlukan intervensi secepatnya untuk mengatasi komplikasi tersebut tidak ditemukan pada penelitian ini.

Sampai saat ini belum ada terapi HI pada anak yang memuaskan. Setelah dijumpai waktu lahir, HI sering menunjukkan perkembangan cepat (fase proliferasi) pada usia 3-9 bulan, diikuti dengan fase stabilisasi (6-9 bulan) dan involusi pada usia 2-9 tahun dengan perubahan warna dan penyusutan komponen subkutan. Kelainan HI akan mengecil perlahan sampai akhirnya sembuh total pada sebagian besar kasus dan sekitar usia 10 tahun, proses involusi ini biasanya selesai. Pada umumnya HI akan mengalami regresi $50 \%$ pada usia 5 tahun, $75 \%$ usia 7 tahun dan 90\% usia 9 tahun. Kulit bisa menjadi normal kembali atau meninggalkan cacat berupa bercak keputihan atau parut. Bila tidak ada penyulit atau komplikasi yang dijumpai khususnya bagi HI yang berlokasi di wajah atau alat kelamin HI sebaiknya diterapi sebelum masa pertumbuhan cepat. ${ }^{4,34}$

Terapi kortikosteroid sistemik adalah suatu cara yang mudah dan efektif sebagai terapi HI pada anak, akan tetapi hasilnya tidak seragam dan pada beberapa jenis tertentu kadang tidak menunjukkan respon. ${ }^{6,8,32,35}$ Terapi kortikosteroid oral jangka panjang dapat menimbulkan efek samping yang buruk seperti gangguan pertumbuhan, efek Cushingoid dan infeksi. ${ }^{36-38}$ Efek samping lain dari kortikosteroid yang pernah dilaporkan adalah penekanan sistem immun dengan mengurangi migrasi neurophil ketempat peradangan, sebaiknya hindari pemberian vaksinasi kuman hidup terhadap pasien yang mendapat terapi jangka panjang kortikosteroid. ${ }^{26}$ Aviles melaporkan adanya infeksi Pneumocystis carinii pada anak usia 3 bulan dengan HI setelah diberikan methyl prednisolon $3 \mathrm{~m} / \mathrm{kgbb} / \mathrm{hari}$ intravena selama 6 minggu. ${ }^{39}$ Dosis kortikosteroid yang diberikan secara intralesi hingga saat ini belum ada kesepakatan dan tidak ada pedoman yang jelas mengenai dosis minimal yang masih efektif. Penyuntikkan dihentikan bila dalam observasi tidak ada respon setelah diberikan maksimum 3 dosis. ${ }^{8,9}, 40$ Kortikosteroid intralesi hanya diberikan pada hemangioma yang kecil ( diameter 2 $3 \mathrm{~cm}$ ) selama 6 minggu dengan dosis tidak lebih dari 3 mg per kilogram berat badan. ${ }^{26}$ Pemberian dosis tinggi steroid intralesi tidak ada hubungan dengan efek samping sistemik selama tempat pemberiannya terkumpul pada hemangioma, karena konsentrasi yang tinggi kortikosteroid pada tempat tersebut sangat efektif untuk mengurangi hemangioma dengan cepat. ${ }^{6,8,41}$ Mekanisme kortikosteroid terhadap HI belum diketahui secara pasti, namun diketahui steroid dapat menghambat proliferasi pericytes immature, memacu efek vasokonstriksi epinefrin dan norepinefrin pada otot polos, menghambat reseptor estradiol dan angiogenesis. ${ }^{33}$ Pemakaian kortikosteroid sistemik pada tahap proliferasi, dapat menghambat pertumbuhan serta menyebabkan regresi hemangioma sekitar 30\% - 90\% dan dapat pula mencegah terjadinya ulserasi sehingga mepercepat penyembuhan. ${ }^{26}$

Penelitian ini menunjukkan bahwa kelompok terapi kortikosteroid oral maupun intralesi memberikan hasil yang baik. Dalam hal ini terapi steroid intralesi sedikit lebih baik dibanding dengan steroid oral. Hasil ini tidak jauh berbeda dengan penelitian yang dilakukan oleh Egbert dkk, ${ }^{8}$ Nelson dkk, ${ }^{9}$ Ranchod dkk, ${ }^{36}$ serta Bennet dkk. ${ }^{42}$ Kortikosteroid merupakan terapi lini pertama pada pengobatan hemangioma, hasil pengobatannya masih bervariasi antara 30\% - 60\%. Pada beberapa kasus ditemukan resisten terhadap pengobatan dengan kortikosteroid sehingga perlu dipakai jenis terapi alternatif lain. Vincristine yang merupakan alcaloid vinca adalah suatu inhibitor mitotik dengan cara menghambat mitosis sel dimetafase. Perez $\mathrm{dkk}^{14}$ memberikan vincristine dengan dosis $2 \mathrm{mg} / \mathrm{m} 2$ per minggu selama 5 minggu pada kasus HI yang resisten terhadap kortikosteroid dan mendapatkan hasil yang baik serta tidak ditemukan tanda-tanda toksisitas. Pada penelitian ini didapatkan respon yang baik pada semua pasien yang diterapi dengan vincristine.

Alternatif lain pengobatan terhadap hemangioma telah banyak dilaporkan beberapa penelitian. Interferon alfa dengan dosis awal $3 \times 10^{6} \mathrm{U} / \mathrm{m}^{2}$ perhari dilaporkan berhasil baik untuk mengobati hemangioma yang resisten terhadap kortikosteroid. Interferon akan 
menghambat proliferasi sel endotel terutama terhadap pengaturan pertumbuhan fibroblast dan faktor angiogenik lain. ${ }^{32,33,43,45}$ Terapi laser biasanya dilakukan terhadap komplikasi hemangioma superfisial berupa ulserasi, berdarah atau untuk tujuan kosmetik. ${ }^{46,47}$

\section{Kesimpulan}

Kortikosteroid sistemik dan intralesi pada penelitian ini cukup efektif terhadap pengobatan HI, hemangioma mengecil serta tidak ditemukan efek samping lokal, sistemik maupun neuro psikiatri. Vincristine dapat dipakai sebagai alternatif pengobatan $\mathrm{HI}$ yang resisten terhadap kortikosteroid.

\section{Daftar Pustaka}

1. Mulliken JB, Glowacki J. Hemangiomas and vascular malformations in infants and children: a classification based on endothelial characteristics. Plast Reconstr Surg 1982; 69:412-22.

2. Senthilkumar M, Thappa DM. Vascular nevi in children. Indian J Dermatol Venereol Leprol 2006;72:19-23.

3. Smolinski KN, Yan AC. Hemangiomas of infancy: clinical and biological characteristics. Clin Pediatr (Phila) 2005; 44:747-66.

4. Oak SN, Viswanath N. Management of hemangiomas in children. Indian J Dermatol Venereol Leprol 2006; 72:1-4.

5. Berenguer B, Mulliken JB, Enjolras O. Rapidly involuting congenital hemangioma: clinical and histopathologic features. Pediatr Dev Pathol 2003; 6:495-510.

6. Delesalle F, Staumont D, Houmany MA, Breviere GM, Piette F. Pulse methylprednisolone therapy for threatening periocular haemangiomas of infancy. Acta Derm Venereol 2006; 86:429-32.

7. Garzon MC, Lucky AW, Hawrot A, Frieden IJ. Ultrapotent topical corticosteroid treatment of hemangiomas of infancy. J Am Acad Dermatol 2005; 52:281-6.

8. Ranchod TM, Frieden IJ, Fredrick DR. Corticosteroid treatment of periorbital haemangioma of infancy: a review of the evidence. Br J Ophthalmol 2005; 89:1134-8.

9. Egbert JE, Paul S, Engel WK, Summers CG. High injection pressure during intralesional injection of corticosteroids into capillary hemangiomas. Arch Ophthalmol 2001; 119:677-83.
10. Sloan GM, Reinisch JF, Nichter LS, Saber WL, Lew K, Morwood DT. Intralesional corticosteroid therapy for infantile hemangiomas. Plast Reconstr Surg 1989; 83: 459-67.

11. O'Keefe M, Lanigan B, Byrne SA. Capillary haemangioma of the eyelids and orbit: a clinical review of the safety and efficacy of intralesional steroid. Acta Ophthalmol Scand 2003; 81:294-8.

12. Kontzoglou G, Triaridis S, Noussios G, Valeri R, Nanas C. Subglottic hemangioma treated with interferon alpha 2A. Acta Otorhinolaryngol Belg 2002; 56:83-5.

13. Greinwald JH, Jr., Burke DK, Bonthius DJ, Bauman NM, Smith RJ. An update on the treatment of hemangiomas in children with interferon alfa-2a. Arch Otolaryngol Head Neck Surg 1999; 125:21-7.

14. Perez J, Pardo J, Gomez C. Vincristine-an effective treatment of corticoid-resistant life-threatening infantile hemangiomas. Acta Oncol 2002; 41:197-9.

15. Pienaar C, Graham R, Geldenhuys S, Hudson DA. Intralesional bleomycin for the treatment of hemangiomas. Plast Reconstr Surg 2006; 117:2216.

16. Gottschling S, Schneider G, Meyer S, Reinhard H, Dill-Mueller D, Graf N. Two infants with lifethreatening diffuse neonatal hemangiomatosis treated with cyclophosphamide. Pediatr Blood Cancer 2006; 46:239-42.

17. Buckmiller L. Update on hemangiomas and vascular malformations. Curr Opin Otolaryngol Head Neck Surg 2004; 12:476-87.

18. Jianhong L, Xianliang $\mathrm{H}$, Xuewu J. Transcatheter arterial embolization in the treatment of extensive maxillofacial hemangioma in children. World J Surg 2005; 29:1550-6.

19. Macarthur CJ. Head and neck hemangiomas of infancy. Curr Opin Otolaryngol Head Neck Surg 2006; 14:397-405.

20. Sari N, Yalcin B, Akyuz C, Haliloglu M, Buyukpamukcu M. Infantile hepatic hemangioendothelioma with elevated serum alpha-fetoprotein. Pediatr Hematol Oncol 2006; 23:639 47.

21. Phung TL, Hochman M, Mihm MC. Current knowledge of the pathogenesis of infantile hemangiomas. Arch Facial Plast Surg 2005; 7:319 21.

22. Walter JW, Blei F, Anderson JL, Orlow SJ, Speer MC, Marchuk DA. Genetic mapping of a novel familial form of infantile hemangioma. Am J Med Genet 1999; 82: 77-83.

23. Krol A, MacArthur CJ. Congenital hemangiomas: 
rapidly involuting and noninvoluting congenital hemangiomas. Arch Facial Plast Surg 2005; 7:30711.

24. Chiller K, Passaro D, Frieden I. Hemangioma of infancy; clinical characteristics, morphology subtypes, and their relationship to race, ethnicity, and sex. Arch Dermatol 2002; 138:1567-76.

25. Haggstrom AN, Drolet BA, Baselga E, et al. Prospective study of infantile hemangiomas: clinical characteristics predicting complications and treatment. Pediatrics 2006; 118:882-7.

26. Metry D, Hebert AA. Benign cutaneous vascular tumor of infacy; when to worry, what to do. Arch Dermatol 2000;136:905-14

27. Garzon M. Hemangiomas: update on classification, clinical presentation, and associated anomalies. Cutis 2000; 66:325-8.

28. Metry D, Hawrot A, Altman C, Frieden I. Association of solitary, segmental hemangiomas of the skin with visceral hemangiomatosis. Arch Dermatol 2004; 140: 591-6.

29. Bruckner AL, Frieden IJ. Infantile hemangiomas. J Am Acad Dermatol 2006; 55:671-82.

30. Metry DW, Haggstrom AN, Drolet BA. A prospective study of PHACE syndrome in infantile hemangiomas: demographic features, clinical findings, and complications. Am J Med Genet A 2006; 140:97586.

31. Schwartz SR, Blei F, Ceisler E, Steele M, Furlan L, Kodsi S. Risk factors for amblyopia in children with capillary hemangiomas of the eyelids and orbit. J Aapos 2006; 10:262-8.

32. Wananukul S, Nuchprayoon I, Seksarn P. Treatment of Kasabach-Merritt syndrome: a stepwise regimen of prednisolone, dipyridamole, and interferon. Int J Dermatol 2003; 42:741-8.

33. North PE, Waner M, James CA, Mizeracki A, Frieden IJ, Mihm MC, Jr. Congenital nonprogressive hemangioma: a distinct clinicopathologic entity unlike infantile hemangioma. Arch Dermatol 2001; 137: 1607-20.

34. Chan YC, Giam YC. Guidelines of care for cutaneous haemangiomas. Ann Acad Med Sin 2005; 34:11723.

35. Dourmishev LA, Dourmishev AL. Craniofacial cavernous hemangioma: succesful treatment with methylprednisolone. Acta Dermatovenerol Alp Panonica Adriat 2005; 14:49-52.

36. Bennett JE. Re: Apfelberg et al: a preliminary study of the combined effect of neodymium: YAG laser photocoagulation and direct steroid instillation in the treatment of capillary/cavernous hemangiomas of infancy. Ann Plast Surg 1989; 23:375.

37. Blei F, Chianese J. Corticosteroid toxicity in infant treated for endangering hemangiomas: experience and guidelines for monitoring. Int Ped 1999;14:146-153.

38. George ME, Sharma V, Jacobson J, Simon S, Nopper AJ. Adverse effects of systemic glucocorticosteroid therapy in infants with hemangiomas. Arch Dermatol 2004; 140:963-9.

39. Iwanaka T, Tsuchida Y, Hashizume K, Kawarasaki H, Utsuki T, Komuro H. Intralesional corticosteroid injection with short-term oral prednisolone for infantile hemangiomas of the eyelid and orbit. J Pediatr Surg 1994; 29:482-6.

40. Park EA, Seo JW, Lee SW, Choi HY, Lee SJ. Infantile hemangioendothelioma treated with high dose methylprednisolone pulse therapy. J Korean Med Sci 2001; 16:127-9.

41. Nelson LB, Melick JE, Harley RD. Intralesional corticosteroid injections for infantile hemangiomas of the eyelid. Pediatrics 1984; 74:241-5.

42. Aviles R, Boyce TG, Thompson DM. Pneumocystis carinii pneumonia in a 3-month-old infant receiving high-dose corticosteroid therapy for airway hemangiomas. Mayo Clin Proc 2004; 79:243-5.

43. Dannenberg H, Brachmann I, Thomas C. [On the relation between steroids and carcinogenic compounds (V). 2-Acetamino- and 3-acetamino-delta 1.3.5.(10) estratrienol-(17beta)]. Z Krebsforsch 1968; 71:74-80.

44. Some Nina K, Lorette G, Chantepie A, Villerette C, Machet L. Hypertrophic cardiomyopathy associated with oral corticosteroid therapy for palpebral hemangioma. Ann Dermatol Venereol 2004; 131:263-5.

45. Fledelius HC, Illum $\mathrm{N}$, Jensen $\mathrm{H}$, Prause JU. Interferon-alfa treatment of facial infantile haemangiomas: with emphasis on the sight-threatening varieties. A clinical series. Acta Ophthalmol Scand 2001; 79:370-3.

46. Sivarajan V, Maclaren WM, Mackay IR. The effect of varying pulse duration, wavelength, spot size, and fluence on the response of previously treated capillary vascular malformations to pulsed-dye laser treatment. Ann Plast Surg 2006; 57:25-32.

47. Chiummariello S, Mezzana P, Fioramonti P, Onesti MG, Alfano C, Scuderi N. The use of laser and varioscope in the management of hemangiomas and vascular malformations. Acta Chir Plast 2006; 48:20-5. 